\title{
A comparative field study of growth, survival and reproduction of Crassostrea gigas, C. angulata and their hybrids
}

\author{
Patrick Soletchnik ${ }^{\mathrm{a}, *}$, Arnaud Huvet ${ }^{\mathrm{b}, 1}$, Olivier Le Moine ${ }^{\mathrm{a}}$, Daniel Razet ${ }^{\mathrm{a}}$, \\ Philippe Geairon ${ }^{\text {a }}$, Nicole Faury ${ }^{\text {a }}$, Philippe Goulletquer ${ }^{\text {a }}$, Pierre Boudry ${ }^{\text {b }}$ \\ a Laboratoire Conchylicole de Poitou Charentes, IFREMER, 17390 La Tremblade, France \\ bLaboratoire de Génétique et Pathologie, IFREMER, 17390 La Tremblade, France
}

Received 22 October 2001; accepted 21 May 2002

\begin{abstract}
This paper reports a comparative study of two cupped oysters, Crassostrea gigas and C. angulata, and their hybrids reared in the Marennes-Oléron Sound (France) under usual farming conditions. The relative proficiency of these species was characterized in terms of growth, survival and reproduction, three major concerns for oyster farming. Four populations of each taxon were sampled (C. gigas: Japan and France; $C$. angulata: Taiwan and Spain) and used as progenitors to produce six different progenies under common hatchery and nursery conditions (transfer of 5 to $6 \mathrm{~g}$ of seed oysters at sea and rearing in bags for 2 years). Mortality profiles differed greatly among the progenies. The $C$. angulata progeny of Taiwanese origin gave the poorest results, with $100 \%$ mortality during the second year. For the entire rearing period, the highest yield $(+22 \%)$ was obtained with the $C$. gigas progeny of French origin. The sexual maturation index, lipid cycles and dry weight loss after spawning showed that spawning of $C$. angulata was delayed by about two weeks compared to that of $C$. gigas. A clear maternal effect was observed for the growth and reproductive characteristics of the hybrids. On the whole, $C$. gigas of French origin gave the best aquacultural results. However, severe episodes of $C$. gigas mortality have been observed in France in recent years, indicating that this species might not be entirely suitable for sustained oyster farming in this country. (C) 2002 Ifremer/CNRS/Inra/IRD/Cemagref/Éditions scientifiques et médicales Elsevier SAS. All rights reserved.
\end{abstract}

\section{Résumé}

Une étude comparative de croissance, taux de survie et reproduction de Crassostrea gigas, C. angulata et de leurs hybrides, en conditions d'élevage traditionnel. Cette étude présente une analyse comparative des deux taxons d'huîtres creuses Crassostrea gigas et Crassostrea angulata et de leurs hybrides élevés dans des conditions d'élevage traditionnel. L'objectif principal est de caractériser leurs performances de croissance, survie et reproduction, trois caractères génétiques d'intérêt essentiel pour l'ostréiculture. Quatre populations des deux taxons ( $C$. gigas: Japon et France; $C$. angulata: Taiwan et Espagne) servent de géniteurs pour produire six populations (descendance) en écloserie et nurserie. Les jeunes huîtres de 5-6 g sont ensuite transférées en mer et élevées en poches ostréicoles pendant 2 ans suivant les pratiques culturales des professionnels du Bassin de Marennes Oléron (France). La dynamique de mortalité est différente selon les descendants. La plus mauvaise réponse est obtenue pour C. angulata d'origine taiwanaise qui présente $100 \%$ de mortalité durant la seconde année. Durant toute la période d'élevage, le meilleur rendement de production (+22\%) est obtenu pour la descendance $C$. gigas d'origine française. L'indice de maturité sexuelle, les cycles lipidiques de la chair des huîtres ou la perte de poids de chair lors de la ponte, montrent que la ponte de $C$. angulata est plus tardive, décalée d'une quinzaine de jours par rapport à celle de $C$. gigas. Un effet maternel sur la croissance et la reproduction des hybrides est nettement mis en évidence. Globalement, $C$. gigas d'origine française présente les meilleures performances d'élevage de toutes les populations étudiées. Toutefois, les manifestations d'épisodes de mortalité de $C$. gigas en France ces dernières années, montrent que cette espèce n'est pas toujours parfaitement adaptée à son environnement ostréicole. (C) 2002 Ifremer/CNRS/Inra/IRD/Cemagref/Éditions scientifiques et médicales Elsevier SAS. Tous droits réservés.

Keywords: Oyster farming; Hybrids; Phenotypes; Crassostrea gigas; Atlantic coast

\footnotetext{
* Corresponding author: IFREMER, 17390 La Tremblade, France.

E-mail address: patrick.soletchnik@ifremer.fr (P. Soletchnik).

${ }^{1}$ Present address: Laboratoire de Physiologie des Invertébrés, IFREMER, B.P. 70, 29280 Plouzané, France
} 


\section{Introduction}

The Marennes-Oléron Sound $\left(150 \mathrm{~km}^{2}\right)$ is an intensive cupped oyster farming area on the Atlantic coast of France. The stock of cupped oysters in these waters is currently 110 000 tons, and an annual production of nearly 40000 tons (i.e. 25\% of total French production) makes it the largest oyster-farming region in Europe. It is also one the most important areas for spat collection. The added value of these activities is extremely important to the regional economy. Production was initially based on the Portuguese oyster, Crassostrea angulata, but currently relies on the Pacific oyster, $C$. gigas. This "replacement" of one taxon by another occurred when $C$. angulata was severely affected by a viral disease in the late 1960s and C. gigas was introduced in the early 1970s to support local farming production (Grizel and Héral, 1991). C. gigas has also been introduced into many other regions of the world, including Canada (1912), Australia (1952; Thompson, 1952, 1958), New Zealand (1972; Smith et al., 1986), Chile and South Africa. It is particularly appreciated for fast growth and resistance to high turbidity levels and temperature variations (Smith et al., 1986; Grizel, 1996).

Among the 20 species described in the Crassostrea genus, the Portuguese oyster (C. angulata; Lamarck, 1819) and the Pacific oyster (C. gigas; Thunberg, 1793) were initially considered to be different species on the basis of geographical distribution. C. angulata was first described along the coasts of southern Europe and C. gigas in Asia (Japan, China). However, many studies demonstrated their very close biological similarity, which has led to their classification as a single species (Menzel, 1974; Huvet et al., 2002). Differences in morphology are almost imperceptible (Ranson, 1967), their karyotypes are close (Leitão et al., 1999a,b), and studies with allozymic markers have failed to detect any significant variations (Mathers et al., 1974; Buroker et al., 1979; Mattiucci and Villani, 1983). However, genetic differences between $C$. angulata and $C$. gigas have been observed. Two studies on the mitochondrial cytochrome oxidase subunit I (COI) gene have shown a clear genetic difference between the two taxa and suggested that C. angulata is of Asian origin (O'Foighil et al., 1998; Boudry et al., 1998). This hypothesis and the close genetic identity between the two cupped oysters were confirmed by a recent study using microsatellite markers, which showed slight but significant genetic differences between $C$. angulata and C. gigas populations (Huvet et al., 2000). Finally, experimental hybridization between these taxa has been clearly demonstrated (Imai and Sakai, 1961; Menzel, 1968; Numachi, 1977; Gaffney and Allen, 1993). More recently, investigations of pre-zygotic and post-zygotic reproductive barriers have confirmed the absence of reproductive isolation between the two taxa (Huvet et al., 2001; 2002).

Nevertheless, significant phenotypic differences have been observed between these two taxa. The yield of $C$. gigas in the natural environment in France was higher (Héral,
1986; Héral et al., 1983), with a growth rate twice that of C. angulata (Bougrier et al., 1986). Analyses of spawn from both taxa in their natural environment (Marennes-Oléron Sound) suggested non-synchronized hatching periods. Differences in their ecophysiological characteristics were also noted (His, 1972; Goulletquer et al., 1999). Moreover, a recent comparative study of ecophysiological performance showed that scope for growth, calculated non-stop over periods of several hours, was significantly greater for $C$. gigas than C. angulata (Haure, pers. com.). Thus, although most authors now consider $C$. angulata and $C$. gigas as a single species, genetically distinct populations clearly show different ecophysiological characteristics.

In this context, the present study compared the aquacultural proficiency (i.e. growth, survival and reproduction) of C. gigas, $C$. angulata and their hybrids under customary farming conditions in the Marennes-Oléron Sound (France). In order to test for local adaptation, the comparisons were performed using $C$. gigas and $C$. angulata progenies originating from native (Japan, Taiwan) and introduced (France and Spain) populations.

\section{Materials and methods}

\subsection{Experimental site}

The Marennes-Oléron Sound is situated along the Atlantic coast of France between La Rochelle and Marennes. An experimental site within a 250 ha oyster bed (RoncePerquis) in the southern part of the sound has been used since 1996 for oyster-farming studies (Lodato, 1997; Soletchnik et al., 1999). The sea floor at this site is a mixture of sand and mud, and the emersion rate is $40 \%$.

\subsection{Biological material}

Four populations were collected: $C$. angulata from Spain (Canio Sancti Pietri, Cadiz) and Taiwan (Keelung), and $C$. gigas from France (Seudre Estuary in the Marennes-Oléron Sound) and Japan (Hiroshima). The initial classification of the oysters by geographical origin was confirmed by polymerase chain reaction-restriction fragment length polymorphism (PCR-RFLP) analysis on COI mitochondrial marker (Boudry et al., 1998).

To prevent any environmental or age effect, the comparative study involved progenies reared under common conditions. In a first experiment, four crosses were performed, using 35 parents from each of the two European populations (C. angulata from Cadiz and C. gigas from the Seudre Estuary). The G1 progeny were pure $C$. gigas (GG), pure $C$. angulata (AA), a hybrid derived from $C$. angulata females and $C$. gigas males (AG), and a hybrid derived from $C$. gigas females and $C$. angulata males (GA) (Fig. 1). The details of the experimental crosses are reported in Huvet et al. (2002). 


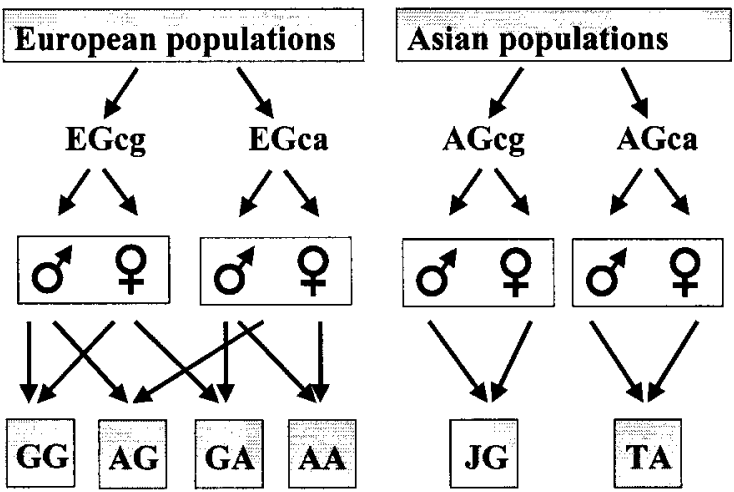

Fig. 1. Experimental crosses made to produce the 6 different progenies: GG, AG, GA, AA, JG and TA from parental populations of Europe (EGcg, EGca) and Asia (AGcg, AGca).

A second experiment involving two crosses within each of the Asiatic populations was conducted using the same procedure. The G1 progeny were pure $C$. gigas from the Japanese population (JG) and pure $C$. angulata from the Taiwanese population (TA) (Fig. 1). These progenies were produced between April and June 1998 under similar rearing conditions. The experiment was subsequently performed over a period of two years, from January 1999 to September 2000, under standard culture conditions, i.e. in oyster bags, each containing 200 individuals, on traditional $50 \mathrm{~cm}$ high oyster-growing tables at the experimental site in the Marennes-Oléron Sound. Five oyster bags were prepared for each of the six progenies. Two of the five bags were used for measurements and analyses and the other three to monitor mortality. Sampling was performed every two weeks.

\subsection{Biological parameters}

The individual parameters recorded were (1) total weight (to the nearest $0.1 \mathrm{~g}$ ), (2) shell weight (after oven-drying at $60{ }^{\circ} \mathrm{C}$ for $24 \mathrm{~h}$, to the nearest $0.1 \mathrm{~g}$ ) and (3) meat dry weight (after freeze-drying for $36 \mathrm{~h}$, to the nearest $0.01 \mathrm{~g}$ ). A tissue sample was taken from the gonad of each oyster, and biometric analysis was performed using a light microscope to determine sex and the maturation index. The maturation index was defined using a four-level scale according to sex (Soletchnik et al., 1997): $0=$ undifferentiated oyster; $1=$ spermatozoa visible but not mobile, i.e. oocytes at the first stage of development; 2 = mobility observed among the spermatozoa, i.e. vitellogenesis underway; and $3=$ spermatozoa highly mobile, i.e. vitellogenesis at an advanced stage and oocytes all mature. To monitor gametogenesis in each progeny, 30 oysters were observed per sample, and the mean maturation index was calculated.

Biochemical analyses of meat were performed on each batch in 3 replicated pools of 10 oysters. Spectrophotometric analysis was conducted on an aliquot of ground tissues of each pool to measure protein content (Lowry et al., 1900), lipid content (Marsh and Weinstein, 1966) and carbohydrate and glycogen content (Dubois et al., 1956; Soletchnik et al., 1997). The results are expressed in $\mathrm{mg}$ of lipid, carbohydrate, glycogen and protein, as a function of total meat weight.

Mortality was monitored only during the second year of the study by counting the number of dead oysters in each bag. One of the bags of the "GA" progeny was accidentally lost, so only two bags were monitored for this progeny. The daily mortality rate $(\mathrm{dmr})$ was calculated for each period: $\mathrm{dmr}=[($ initial number - final number $) /$ ( final number + initial number $/ 2] /$ number of days $\times 100$. The final yield was estimated as yield $(\%)=($ final biomass initial biomass) / initial biomass. Biomass, corresponding to the mean weight of oysters in the bag multiplied by the number of individuals present, took both growth and mortality into account.

\subsection{Statistical analysis}

Statistical analyses of total wet weight and meat dry weight, including tests of normality, were performed using analysis of variance and multiple comparison tests according to the least szignificant difference (LSD) method (Cochran and Cox, 1957), using Statgraphics version 3.1 software. Cumulated mortalities were converted into angular arc sine $V(\%$ of mortality) before analysis.

\section{Results}

\subsection{Mortality}

Mortality differed significantly among progenies $(\mathrm{F}=4.24 ; p=0.0335): 29,33,33,19,24$ and $100 \%$ for the AA, AG, GA, GG, JG and TA respectively (Fig. 2). The LSD test revealed two statistically different groups: (1) GG and JG; and (2) JG, AA, AG and GA. All TA oysters died before the beginning of July 2000. The AA, AG and GA progenies underwent several mortality phases between April and July (Fig. 2). The daily mortality rate for GG and JG was about $0.1 \%$ during winter and increased to $0.25-0.40 \%$ during the spawning period.

\subsection{Growth}

The curves showed 2 growth periods, summer and spring, separated by a fall and winter period without any notable growth (Fig. 3). Dry weight variations followed a similar pattern. A first loss in dry weight $(0.20$ to $0.35 \mathrm{~g})$ occurred between October 1999 and February 2000. A second and much greater loss occurred during the summer of 2000, after spawning. In 18 months, the total weight increased from 5-6 g to about $30 \mathrm{~g}$ for AA, AG and JG, more than $40 \mathrm{~g}$ for GA, and more than $50 \mathrm{~g}$ for GG (Fig. 3). A similar trend was observed for dry weight (Fig. 3). At the beginning of July, dry weight ranged from $1.15 \mathrm{~g}$ to $1.35 \mathrm{~g}$ 

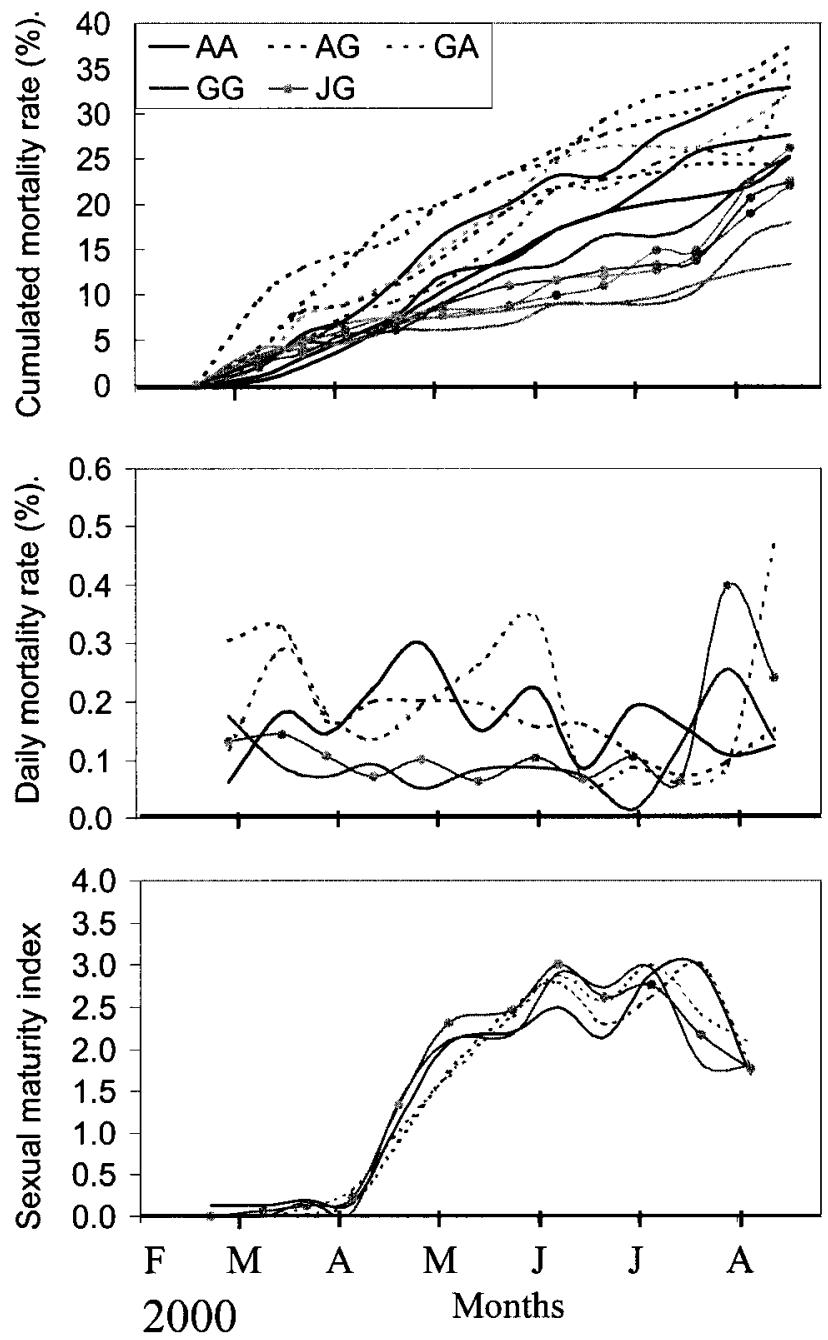

Fig. 2. Cumulative mortality rates, seasonal mortality rates (daily mortality rate calculated over a 15 days time span) and sexual maturation of the 6 different progenies between March and August 2000.

$\mathrm{AA}$, pure ECa; AG, hybrid resulting from European $\mathrm{ECa}$ females and $\mathrm{ECg}$ males; GA, hybrids from ECg females and ECa males; GG, pure ECg; JG, $\mathrm{G} 1$ resulting from the Japanese $\mathrm{ACg}$ population.

for AA, AG and JG, but reached $1.50 \mathrm{~g}$ for $\mathrm{GA}$ and $1.80 \mathrm{~g}$ for GG. The slowest growth was observed for AA and AG progenies. Compared to the others, the growth of JG progeny was particularly slow during the end of spring 1999 and the beginning of the first summer (Fig. 3), and even until spring 2000. These results were apparent in analyses of variance for total weight and dry weight after 17 months of culture (Table 1). Three distinct groups were revealed statistically on the basis of total weight data: (1) JG (29 g), AA (31 g), AG (33 g), (2) GA (43 g) and (3) GG (52 g). Only two groups differed statistically for dry weight: (1) JG $(0.85 \mathrm{~g}), \mathrm{AA}(0.87 \mathrm{~g}), \mathrm{AG}(0.90 \mathrm{~g})$ and $(2) \mathrm{GA}(1.22 \mathrm{~g})$ and GG (1.32 g).

\subsection{Reproduction and biochemical composition}

An increase of the maturation index was apparent as early as mid-April, and the maximum value (stage 3 ) was
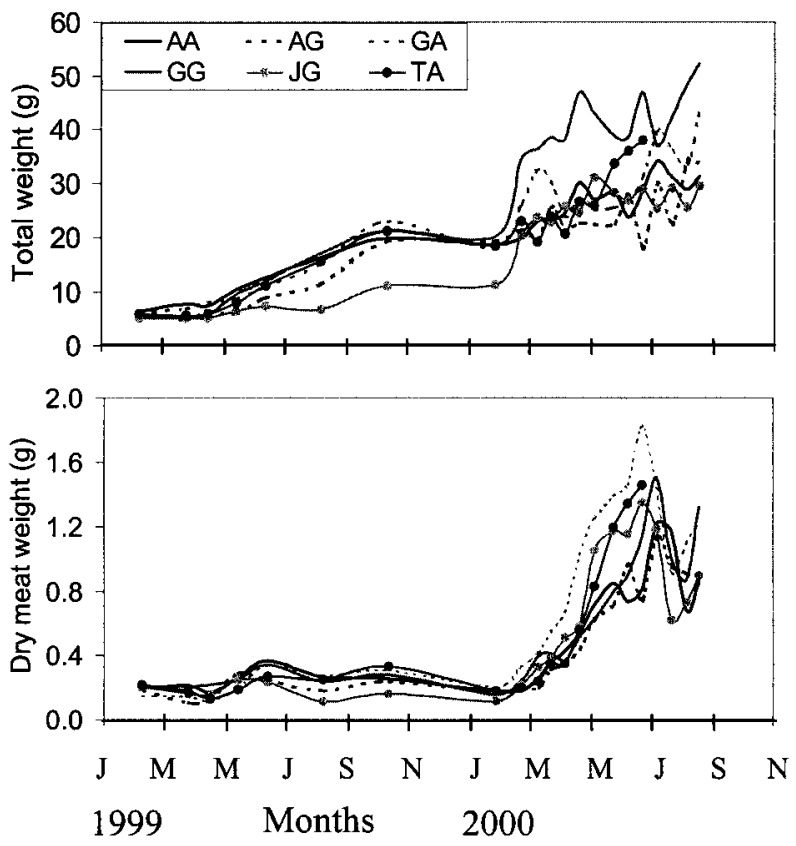

Fig. 3. Total wet weight $(\mathrm{g})$ and dry meat weight $(\mathrm{g})$ of the 6 progenies between March 1999 and August 2000.

$\mathrm{AA}$, pure $\mathrm{ECa}$; $\mathrm{AG}$, hybrid resulting from European $\mathrm{ECa}$ females and $\mathrm{ECg}$ males; GA, hybrids from ECg females and ECa males; GG, pure ECg; JG, G1 resulting from the Japanese ACg population; TA, G1 resulting from the Taiwanese ACa population.

Table 1

Analysis of variance for the total wet weight (g) and dry meat weight (g) by the experiment completion (17 months) for the 6 progenies: $A A$ pure Crassostrea angulata of spanish origin; $A G$ hybrids from Crassostrea angulata females and Crassostrea gigas males ; GA hybrids from Crassostrea gigas females and Crassostrea angulata males; GG pure Crassostrea gigas of Marennes-Oléron origin; JG pure Crassostrea gigas of Japanese origin.

F Fisher test $(\mathrm{F}=19.07)$ and probability $p<0.001$ for total wet weight. F Fisher test $(\mathrm{F}=8.41)$ and probability $p<0.001$ for dry meat weight.

\begin{tabular}{|c|c|c|c|c|}
\hline & Strain & $\begin{array}{l}\text { Weight } \\
\text { (g) }\end{array}$ & $\begin{array}{l}\text { Standard } \\
\text { Error } \\
(\mathrm{g})\end{array}$ & $\begin{array}{l}\text { Homogeneous } \\
\text { groups }\end{array}$ \\
\hline \multirow{5}{*}{$\begin{array}{l}\text { Total wet } \\
\text { weight }\end{array}$} & $\mathrm{JG}$ & 29.4 & 1.9 & A \\
\hline & $\mathrm{AA}$ & 31.2 & 1.7 & A \\
\hline & $\mathrm{AG}$ & 33.6 & 2.0 & A \\
\hline & GA & 43.6 & 2.9 & B \\
\hline & GG & 52.3 & 2.3 & $\mathrm{C}$ \\
\hline \multirow{5}{*}{$\begin{array}{l}\text { Dry meat } \\
\text { weight }\end{array}$} & $\mathrm{JG}$ & 0.85 & 0.06 & A \\
\hline & AA & 0.87 & 0.06 & A \\
\hline & $\mathrm{AG}$ & 0.90 & 0.09 & A \\
\hline & GA & 1.22 & 0.07 & B \\
\hline & GG & 1.32 & 0.10 & B \\
\hline
\end{tabular}

reached in June-July (Fig. 2). Some differences were observed between the progenies. AA and AG had a similar maturation index profile, with a decrease at the beginning of August, whereas the decrease only occurred around midJuly for GG, GA and JG (a delay of about two weeks). Finally, the TA progeny had a completely atypical reproduction profile before complete mortality. 

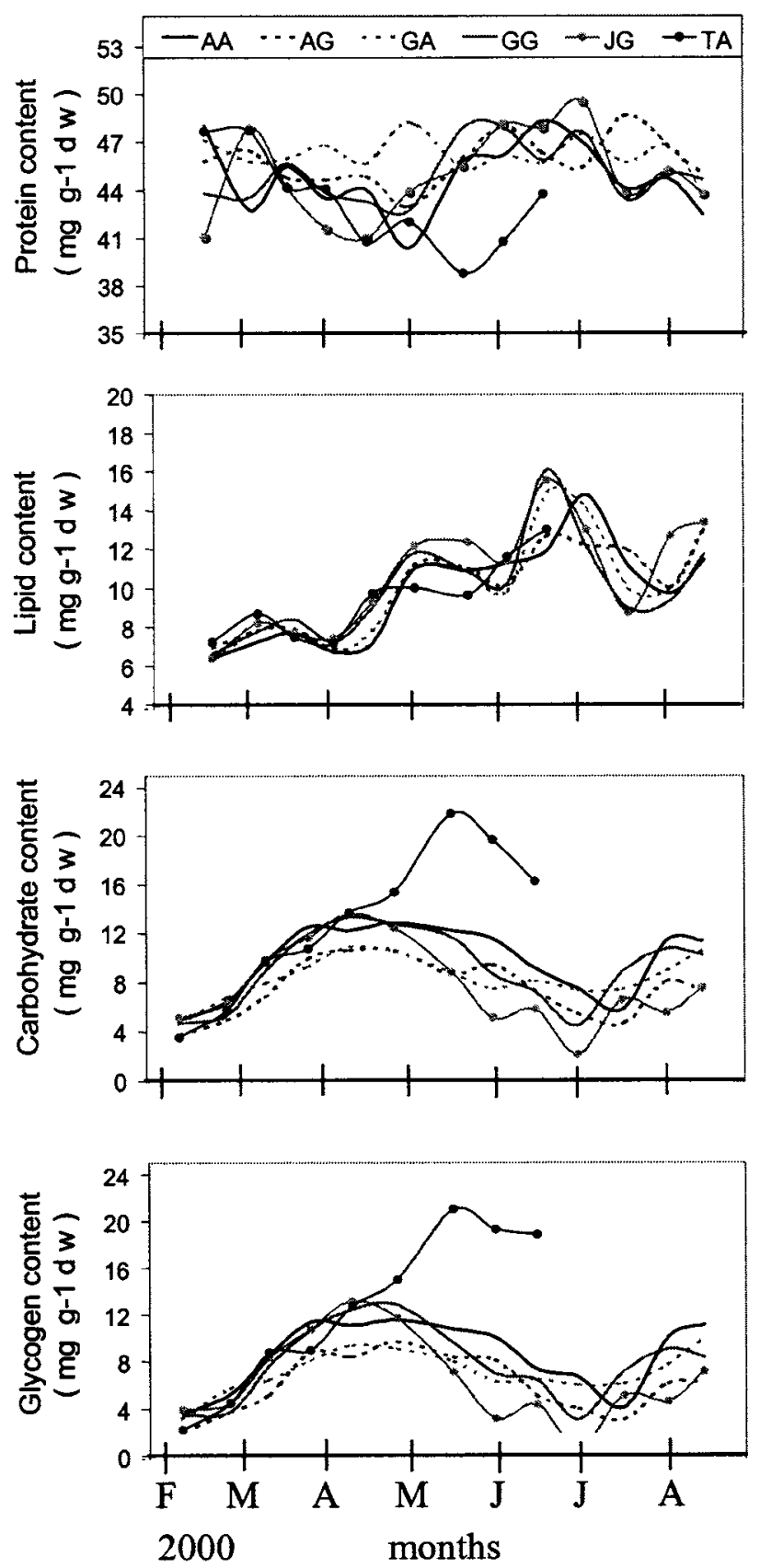

Fig. 4. Proximate biochemical composition of the oyster dry meat (mg. $\mathrm{g}^{-1}$ dry meat weight) over the experimental time period.

AA, pure ECa; AG, hybrid resulting from European ECa females and $\mathrm{ECg}$ males; GA, hybrids from ECg females and ECa males; GG, pure ECg; JG, G1 resulting from the Japanese ACg population; TA, G1 resulting from the Taiwanese ACa population.

Protein content ranged between 41 and $49 \mathrm{mg} \cdot \mathrm{g}^{-1}$ for the different progenies (Fig. 4). Meat lipid content increased from $6 \mathrm{mg} \cdot \mathrm{g}^{-1}$ in March to $14-16 \mathrm{mg} \cdot \mathrm{g}^{-1}$ at the beginning of July. The lipid peak was centered on the first days of July for GG and JG, and occurred in mid-July for AA. An intermediate situation was observed with the hybrids, with a plateau at $14 \mathrm{mg} \cdot \mathrm{g}^{-1}$ and $12 \mathrm{mg} \cdot \mathrm{g}^{-1}$ during the first fortnight of July for $\mathrm{GA}$ and $\mathrm{AG}$ respectively.

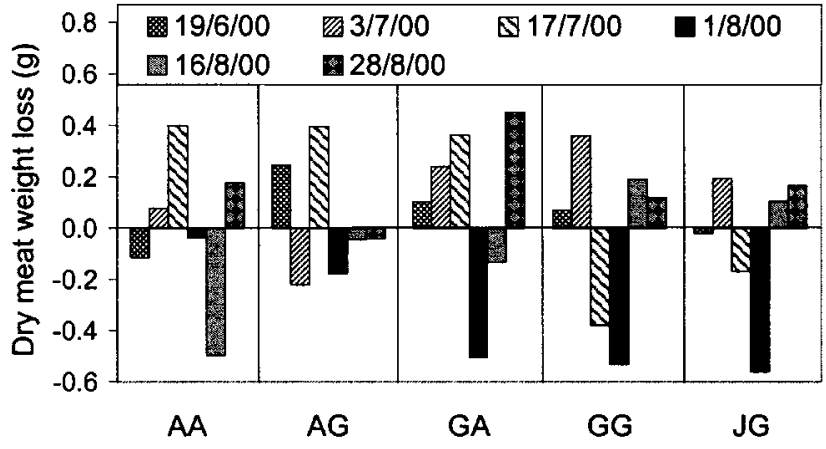

Fig. 5. Dry meat weight loss during the spawning season for the 5 progenies.

AA, pure ECa; AG, hybrid resulting from ECa females and ECg males; GA, hybrids from ECg females and ECa males; GG, pure ECg; JG, G1 resulting from the Japanese $\mathrm{ACg}$ population.

Dry meat carbohydrate content increased during March and April from 4 to $10-14 \mathrm{mg} \cdot \mathrm{g}^{-1}$, depending on the progeny, before falling to its lowest levels ( 2 to $6 \mathrm{mg} \cdot \mathrm{g}^{-1}$ ) during spawning at the end of July. Carbohydrate use was more marked for GG and JG (Fig. 4), i.e. the progenies with the highest weight loss after spawning. Total carbohydrate content was less than $4 \mathrm{mg} \cdot \mathrm{g}^{-1}$ for AA and the GA and AG hybrids, whereas meat glycogen content was close to 0 for JG during the second half of July.

The chronology of dry meat weight loss seemed to differ for each progeny (Fig. 5). The reproductive season for AA appeared to be longest, as weight loss was first observed around mid-June, with a peak around mid-August. The spawning season for JG and GG was between mid-July and the beginning of August. Finally, the hybrids again showed intermediate results, as the heaviest weight loss $(\sim 0.5 \mathrm{~g})$ was recorded at the beginning of August for GA (similarly to GG and $\mathrm{JG}$ ), whereas the mean weight loss of AG was less marked during August.

\subsection{Culture yield and energy use}

In terms of weight gain, GG and GA produced 1.8 to $2.0 \mathrm{~g}$ of meat (soma + gonads), whereas the other three progenies only produced 1.2 to $1.4 \mathrm{~g}$ (Fig. 6). Shell weight gain for GA and GG reached 24 and $29 \mathrm{~g}$ respectively, whereas the other progenies produced between 14 and $17 \mathrm{~g}$. At the end of the year 2000, culture yield was only $5 \%$ for AG hybrids, $10 \%$ for GA and JG and $13 \%$ for AA. Finally, the highest yield (22\%) was obtained for the GG progeny.

\section{Discussion}

\subsection{Growth}

The growth of the different progenies was measured in the southern Marennes-Oléron Sound, an area currently subjected to high anthropic pressure in which several 


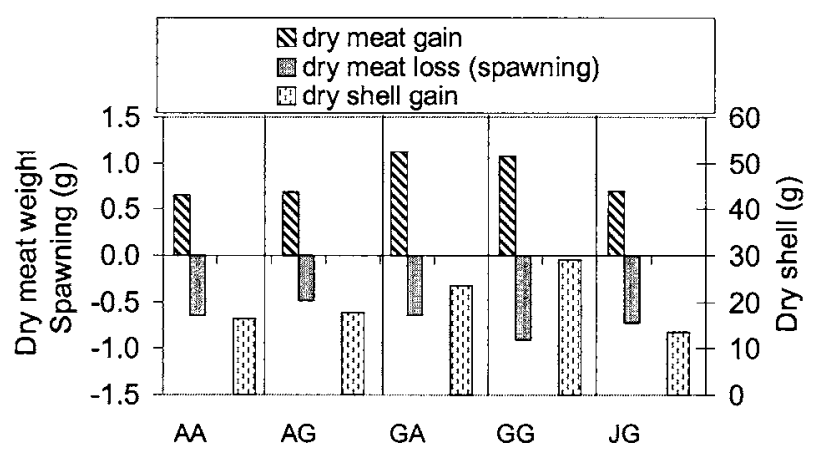

Fig. 6. Somatic growth, shell weight gain and estimated spawning effort for the 5 progenies.

$\mathrm{AA}$, pure $\mathrm{ECa}$; AG, hybrid resulting from ECa females and $\mathrm{ECg}$ males; GA, hybrids from ECg females and ECa males; GG, pure ECg; JG, G1 resulting from the Japanese $\mathrm{ACg}$ population.

episodes of summer mortality have occurred in recent decades (Soletchnik et al., 1998, 1999). Weight loss recordings during winter clearly show the "chronic" overloading of this area since 1985 (Héral et al., 1983). In particular, the southern part of the sound contains $360 \mathrm{~kg}$ of oysters per $1,000 \mathrm{~m}^{3}$, which is undoubtedly too many for optimal growth of the progenies under study (Soletchnik et al., 1998).

The faster growth of $C$. gigas than $C$. angulata strains confirmed previous observations (His, 1972; Barré, 1981; Bougrier et al., 1986; Héral, 1989; Parache, 1989). The $C$. gigas to $C$. angulata growth ratio during the period from the beginning of March to the end of August was 1.55 for total weight, i.e. identical to the ratio recorded in 1970 based on a comparison of the first $C$. gigas oysters introduced into the Marennes-Oléron Sound when $C$. angulata was still present (His, 1972). Hybrid growth showed clear maternal effects. The growth of AG hybrids (produced from $C$. angulata females) was similar to that of $C$. angulata progeny of the same geographic origin (Spain). Moreover, C. gigas progeny of French origin and GA hybrids displayed similar growth rates, which were higher than those of the other progenies.

The geographical origin of the parental population also had an influence on growth. $C$. angulata progeny of Taiwanese origin grew slower than that of Spanish origin. Similarly, $C$. gigas progeny of Japanese origin grew slower than that of French origin. This suggests the existence of genetically based differences between parental populations within each taxon. The $C$. gigas oysters introduced into France were imported from Myagi (Japan) and British Colombia (Canada) (Grizel and Héral, 1991). The Japanese population used in our study was collected in Hiroshima (southern Japan). This suggests that there may be genetically-based differences in growth rates between these two Japanese regions. However, intensive oyster farming in Japan has led to many exchanges of stocks (Ogawa, pers. comm.) and could be responsible for the genetic homogeneity of $C$. gigas populations along Japanese coasts. Alter- natively, the differences observed might be imputable to local adaptation of $C$. gigas oysters since their introduction into France. This could account for their greater efficiency in our experiment. Similarly, Spanish C. angulata progenies exhibited better growth rates than Taiwanese ones.

\subsection{Sexual maturation and spawning}

Reproduction characteristics (sexual maturation index, lipogenesis, dates and extent of spawning) were similar for the two pure $C$. gigas progenies of French and Japanese origin and for the $C$. angulata progeny of Spanish origin. Thus, there would appear to be a taxon-related influence, whereas the geographical origin of the parental populations would seem to have had no effect, except for the Taiwanese strain. Moreover, the parental and hybrid forms had similar reproduction patterns when grouped according to the maternal taxon. The fact that maturation patterns were very similar for $C$. angulata progeny and hybrids produced with $C$. angulata females, as well as for $C$. gigas and hybrids from $C$. gigas females, suggests a maternal effect on the characteristics involved in reproduction. Similar differences in reproduction timing and amplitude were observed in two closely related clam species, Mercenaria mercenaria and $M$. campechiensis, whose hybrids showed a clear maternal effect (Eversole, 1997). Strong maternal transmission of oocyte quality was also suggested with respect to estimated developmental rates in experimental crosses between $C$. gigas and C. angulata populations (Huvet et al., 2002).

$C$. angulata progeny from the Taiwanese population could have had difficulty acclimating to the environmental conditions of the Marennes-Oléron Sound. The biochemical cycles seemed to be totally out of phase with those of the other progenies, which suggests an essential difference in the reproduction seasons of $C$. gigas and $C$. angulata, possibly due to local adaptation. In fact, natural environmental conditions along the Taiwanese coasts where the parental population was sampled are semi-tropical, whereas the other natural populations of $C$. gigas originated from more temperate zones.

\subsection{Mortality}

On the whole, the mortality of $C$. gigas was lower than that of $C$. angulata. Moreover, the geographical origin of the parental animals (European versus Asian) seemed to increase this difference between the taxa, particularly for $C$. angulata of Taiwanese versus Spanish origin. Contrary to the reproductive characteristics, mortality data showed no maternal effect. The highest mortality (up to 30\%) over the six months of monitoring was observed for the two hybrids and the pure $C$. angulata progeny. During the same period, the mortality of $C$. gigas from the Marennes-Oléron Sound was less than $20 \%$, while that of four $C$. gigas populations (two from the Marennes-Oléron Sound and two from Normandy) was $12-15 \%$ at the same site. 


\subsection{Relationship between sexual maturation and mortality}

The yield in terms of shell, spawn and somatic weight gains appeared to be greater for the pure $C$. gigas progeny. The growth ratio was 1.55 in favor of $C$. gigas for total weight between the beginning of March and the end of August, reaching 2.36 in July before spawning. The estimation of reproductive effort, calculated from dry weight loss, was lower for $C$. angulata progeny and the hybrids generated from $C$. angulata females. No positive correlation could be established between weight loss due to spawning and mortality. Even though the lowest mortality was observed with European and Asian $C$. gigas, the only significant mortality peak for this taxon occurred after spawning. In fact, this peak was inversely proportional to the total carbohydrate and glycogen content present in oyster tissues in mid-July (i.e. before spawning). Thus, the pure $C$. gigas progenies (GG and $\mathrm{JG}$ ) seemed to be best adapted to environmental conditions on the foreshore between March and July during the maturation period. As a result, they developed greater weight loss due to spawning, which led to a decrease in carbohydrate reserves that left them weaker and more susceptible to mortality after spawning. The mortality of GG and $\mathrm{JG}$ progenies after reproduction is indicative of oyster fragility during the reproduction period (Soletchnik et al., 1998). This phenomena could result from a degradation of environmental conditions in the southern Marennes-Oléron Sound (Soletchnik et al., 1998) and/or physiological dysfunction associated with the maturation and spawning processes for this taxon (Soletchnik, 2001). Further studies are needed to clarify this point and determine the possible relationship between oyster reproductive characteristics and mortality.

\section{Conclusion}

Production in the Marennes-Oléron Sound, one of the major cupped oyster-farming areas in France, has relied successively on the cultivation of $C$. angulata and $C$. gigas. At the present time, the ecosystem is overexploited and subject to increasing anthropic pressure. In this context, assessment of the aquacultural proficiency of $C$. gigas and C. angulata populations of different geographical origins could provide a mean of sustaining, and possibly improving, local production. Our study shows that $C$. angulata progenies were more often and more intensely affected by mortality. The resulting overall production indicated that the best rates were obtained by $C$. gigas oysters of French origin, followed by hybrids obtained by crossing $C$. gigas females with $C$. angulata males. The mortality profiles, which were clearly different according to taxon, may help elucidate the chronic and acute occurrences of summer mortality that occur with increasing frequency in the Marennes-Oléron Sound.

\section{References}

Barré, D., 1981. Implantation de Crassostrea gigas (Thunberg) dans le bassin de Marennes-Oléron. Veterinary thesis, Université de Toulouse. Bougrier, S., Raguenes, G., Bachère, E., Tigé, G., Grizel, H., 1986. Essai de réimplantation de Crassostrea angulata en France, résistance au chambrage et comportement des hybrides $C$. angulata - C. gigas. ICES, Copenhagen (Denmark). ICES. CM. F/38, pp. 10.

Boudry, P., Heurtebise, S., Collet, B., Cornette, F., Gérard, A., 1998. Differentiation between populations of the Portuguese oyster Crassostrea angulata (Lamark) and Pacific oyster Crassostrea gigas (Thunberg), revealed by mtDNA RFLP analysis. J. Exp. Mar. Biol. Ecol. 226, 279-291.

Buroker, N.E., Hershberger, W.K., Chew, K.K., 1979. Populations genetics of the family Ostreidae. I. Intraspecific studies of Crassostrea gigas and Saccostrea commercialis. Mar. Biol. 54, 157-169.

Cochran, W.G., Cox, G.M., 1957. Experimental Designs. $2^{\text {d }}$ edition. John Wiley and Sons.

Dubois, M., Gilles, K.A., Hamilton, J.K., Rebers, P.A., Smith, F., 1956. Colorimetric method for determination of sugars and related substances. Anal. Chem. 28, 350-356.

Eversole, A.G., 1997. Gametogenesis of Mercenaria mercenaria, $M$. campechiensis and their hybrids. Nautilus 110, 107-110.

Gaffney, P.M., Allen, K.S., 1993. Hybridization among Crassostrea species: a review. Aquaculture 116, 1-13.

Grizel, H., Héral, M., 1991. Introduction into France of the Japanese oyster Crassostrea gigas. J. Cons. Int. Explor. Mer. 47, 399-403.

Grizel, H., 1996. Quelques exemples d'introductions et de transferts de mollusques. Rev. Sci. Tech. Off. Int. Epizooties 15, 401-408.

Goulletquer, P., Wolowicz, M., Latala, A., Geairon, P., Huvet, A., Boudry, P., 1999. Comparative analysis of oxygen consumption rates between cupped oyster spat of Crassostrea gigas of French, Japanese, Spanish and Taiwanese origins. Aquat. Living Resour. 12, 271-277.

Héral, M., Deslous-Paoli, J.M., Sornin, J.M., 1983. Transferts énergétiques entre l'huître Crassostrea gigas de 1 an et la nourriture potentielle disponible dans un bassin ostréicole : premières approches. Océanis 9, 169-194.

Héral, M., 1986. L’ostréiculture française traditionnelle. In: Barnabé, G. (Ed.), Aquaculture, vol 1. Tech. \& Doc. Lavoisier, Paris, pp. 345390.

Héral, M., 1989. Traditional oyster culture in France. In: Barnabé, G. (Ed.), Aquaculture 1. Lavoisier, Paris, pp. 342-387.

His, E., 1972. Premiers éléments de comparaison entre l'huître portugaise et l'huître japonaise. Science et Pêche. Bull. Inst. Pêches Marit. 219, $1-9$.

Huvet, A., Lapègue, S., Magoulas, A., Boudry, P., 2000. Mitochondrial and nuclear DNA phylogeography of Crassostrea angulata, the Portuguese oyster endangered in Europe. Cons. Genet. 1, 251-262.

Huvet, A., Balabaud, K., Bierne, N., Boudry, P., 2001. Microsatellite analysis of 6-hour-old embryos reveals no preferential intra-specific fertilization between cupped oysters Crassostrea gigas or Crassostrea angulata. Mar. Biotech. 3, 448-453.

Huvet, A., Gérard, A., Ledu, C., Phélipot, P., Heurtebise, S., Boudry, P., 2002. Is fertility of hybrids enough to conclude that the two oysters Crassostrea gigas and Crassostrea angulata are the same species? Aquat. Living Resour. 15, 45-52.

Imai, T., Sakai, S., 1961. Study of breeding of Japanese oyster, Crassostrea gigas. Tohoku J. Agric. Res. 12, 125-171.

Leitão, A., Thiriot-Quiévreux, C., Boudry, P., Malheiro, I., 1999a. A “G” chromosome banding study of three cupped oyster species: Crassostrea gigas, Crassostrea angulata and Crassostrea virginica (Mollusca: Bivalvia). Genet. Select. Evol. 31, 519-527.

Leitão, A., Boudry, P., Labat, J.P., Thiriot-Quiévreux, C., 1999b. Comparative kariological study of cupped oyster species. Malacologia 41, 175-186.

Lodato, M.I., 1997. Mortalité estivale de l'huître creuse Crassostrea gigas sur les bancs ostréicoles de Perquis et Ronce (Bassin de Marennes 
Oléron) : étude des pratiques culturales et des caractéristiques biologiques et spatiales des élevages. Veterinary thesis. Ecole Nationale Vétérinaire de Maison Alfort.

Lowry, O.H., Rosebrough, N., Farr, A.L., Randall, R.J., 1951. Protein measurement with the Folin phenol regent. J. Biol. Chem. 193, 265-275.

Marsh, J.B., Weinstein, D.B., 1966. Simple charring method for determination of lipids. J. Lipid Res. 7, 574-576.

Mathers, N.F., Wilkins, N.P., Walne, P.R., 1974. Phosphoglucose isomerase and esterase phenotypes in $C$. angulata and $C$. gigas. Biochem. System. Ecol. 2, 93-96.

Mattiucci, S., Villani, F., 1983. Studio elettroforetico dei sistemi geneenzima in ostriche classificate come Crassostrea gigas (Thunberg, 1793) e Crassostrea angulata (Lamarck, 1819) (Mollusca: Ostreidae). Parasitologia 25, 21-27.

Menzel, R.W., 1968. Cytotaxonomy of species of clams (Mercenaria) and oysters (Crassostrea). Symposium of Mollusca, Mar. Biol. Assoc. India. Part I, 75-84.

Menzel, R.W., 1974. Portuguese and Japanese oysters are the same species. J. Fish. Res. Board Can. 31, 453-456.

Numachi, K., 1977. Japanese species, breed and distribution. In: Imai, T. (Ed.), Aquaculture in Shallow Seas: Progress in Shallow Sea Culture. Amerind Publishing Co., New Delhi, pp. 123-126.

O'Foighil, D., Gaffney, P.M., Wilbur, A.E., Hilbish, T.J., 1998. Mitochondrial cytochrome oxydase I gene sequences support an Asian origin for the Portuguese oyster Crassostrea angulata. Mar. Biol. 131, 497-503.
Parache, A., 1989. Growth performance of oyster Crassostrea angulata and Crassostrea gigas reared in Arcachon Bay between and 1986: First results. Haliotis 19, 227-236.

Ranson, G., 1967. Les espèces d'huîtres vivant actuellement dans le monde, définies par leurs coquilles larvaires ou prodissoconques. Etude des collections de quelques uns des grands musées d'Histoire Naturelle. Rev. Trav. Inst. Pêches Marit. 31, 127-199.

Smith, P.J., Ozaki, H., Fujio, Y., 1986. No evidence for reduced genetic variation in the accidentally introduced oyster Crassostrea gigas in New Zealand. N.Z. J. Mar. Freshw. 20, 569-574.

Soletchnik, P., Razet, D., Geairon, P., Faury, N., Goulletquer, P., 1997. Ecophysiologie de la maturation sexuelle et de la ponte de l'huître creuse Crassostrea gigas : réponses métaboliques (respiration) et alimentaires (filtration, absorption) en fonction des différents stades de maturation. Aquat. Living Resour. 10, 177-185.

Soletchnik, P., Faury, N., Razet, D., Goulletquer, P., 1998. Hydrobiology of the Marennes-Oléron Bay, seasonal indices and analysis of trends from 1978 to 1995 . Hydrobiologia 386, 131-146.

Soletchnik, P., Le Moine, O., Faury, N., Razet, D., Geairon, P., Goulletquer, P., 1999. Mortalité de l'huître Crassostrea gigas dans le Bassin de Marennes-Oléron. Etude de la variabilité spatiale de son environnement et de sa biologie par un système d'information géographique (SIG). Aquat. Living Resour. 12, 131-143.

Soletchnik, P., 2001. Impact of the climatic change on an estuarian ecosystem: the Marennes Oléron Bay. French IGBP-WCRP News Lett. $12,37-41$. 